\title{
Low breeding success and sharp population decline at the largest known Falkland skua colony
}

\author{
Paulo Catry • Ana Almeida • Miguel Lecoq • \\ José Pedro Granadeiro · Rafael Matias
}

Received: 26 November 2010 / Revised: 17 January 2011 / Accepted: 18 January 2011 / Published online: 4 March 2011

(C) Springer-Verlag 2011

\begin{abstract}
The Falkland skua Stercorarius antarctica antarctica is a poorly known seabird. Demographic studies at the largest known colony of this taxon revealed a sharp population decline $(47 \%)$ in just 5 years, between 2004 and 2009. The decline seems to be linked with a chronic low breeding success in the recent years and is consistent with a situation of virtually zero recruitment. The ultimate causes of the decline are, as of yet, unknown, but plausible explanations are examined and discussed. The reported population trends should be the cause of some concern, and more research and monitoring are desired.
\end{abstract}

Keywords New Island · Falkland Islands · Brown skua · Striated caracara $\cdot$ Phalcoboenus australis

The Falkland skua Stercorarius antarctica antarctica, a taxon nearly endemic to the Falkland Islands, is a little studied seabird, for which there are virtually no published ecological or demographic data (but see Lamey 1995; Woods and Woods 1997; Yorio 2005; Phillips et al. 2007).

P. Catry $(\bowtie) \cdot$ A. Almeida $\cdot$ M. Lecoq $\cdot$ R. Matias

Eco-Ethology Research Unit, ISPA, Rua Jardim do Tabaco 34, 1149-041 Lisbon, Portugal

e-mail: paulo.catry@gmail.com

P. Catry

Museu Nacional de História Natural, Rua da Escola Politécnica, Lisbon, Portugal

J. P. Granadeiro

CESAM, Museu Nacional de História Natural,

Rua da Escola Politécnica, Lisbon, Portugal

R. Matias

Centre for Ecology and Conservation, School of Biosciences, University of Exeter, Cornwall Campus, Penryn,

Cornwall TR10 9EZ, UK
New Island $\left(51^{\circ} 43^{\prime} \mathrm{S}, 61^{\circ} 18^{\prime} \mathrm{W}\right)$, on the west of the Falklands, holds the largest known colony of this subspecies (I. J. Stange, pers.com and own unpublished data), which is probably justified by the existence of a large concentration of skua bird prey, particularly thin-billed prions Pachyptila belcheri (Catry et al. 2003). Here, we show that this important colony is in rapid decline and that this is probably linked to a chronically low breeding success in recent years.

Skua breeding territories were censused between 12 and 20 December 2004 (in the incubation period), on the southern half of the island, and between 12 and 28 December 2009 on the whole island (with most of the southern part being visited before 20 December, similarly to 2004). Observers walked slowly covering the whole of the island ground and, using GPS, recorded the position of skua nests or of the centre of occupied territories (Phillips et al. 2004). Nesting sites and territories were easy to locate, due to the high territorial attendance of adult skuas during incubation, to the exceedingly tame nature of the birds (no birds flew away when approached), and to the open low vegetation that covers all nesting areas.

From 2003, we have regularly monitored skua-breeding success on New Island. Each season, a number of preselected territories were regularly visited from the pre-laying stage until the chicks were 40 days old (nearly fledged). Study territories included both pairs nesting close to penguin, cormorant and albatross colonies and pairs on prion colonies. Nest checks did not have any apparent negative effect on skua reproduction, which we would not have expected anyway, given the tame nature of the birds and the fact that no other studies of large skuas have reported such deleterious consequences on the birds.

In December 2004, there were 417 occupied territories in the south part of the island (Fig. 1). In 2009, the number 
Fig. 1 Distribution of Falkland skua breeding territories on New Island in the breeding seasons of 2004-2005 and 2009-2010
2004

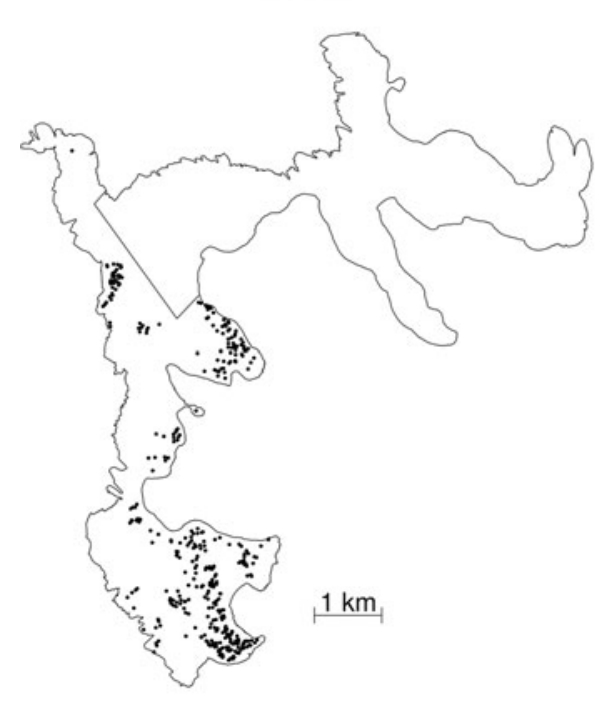

2009

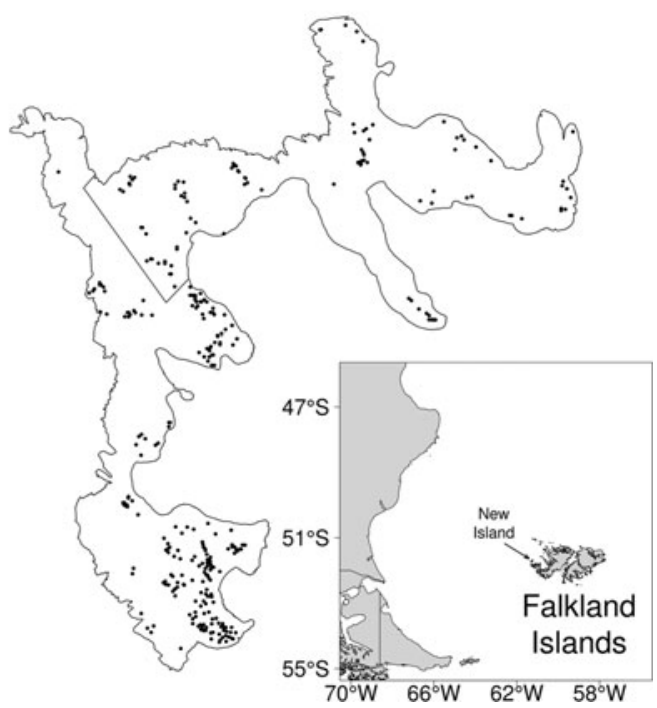

Table 1 Breeding success (number of chicks per nesting pair) of Falkland skuas on New Island in the summer seasons from 2003-2004 to 2009-2010

\begin{tabular}{lccccccc}
\hline Year & 2003 & 2004 & 2005 & 2006 & 2007 & 2008 & 2009 \\
\hline $\begin{array}{l}\text { Breeding } \\
\text { success }\end{array}$ & 0.05 & 0 & 0.35 & 0.53 & 0.80 & 0.23 & 0.44 \\
$N$ & 42 & 26 & 34 & 17 & 10 & 26 & 43 \\
\hline
\end{tabular}

of territories in the same area was 219. The distribution of the breeding population showed little change, but the density of territories decreased from 40.4 territories per $\mathrm{km}^{2}$ in 2004 to 21.2 territories per $\mathrm{km}^{2}$ in 2009. Overall, the number of Falkland Skua territories on New Island South suffered a reduction of $47.5 \%$ in the 5 years between the two surveys, which equates to a decline of $12.1 \%$ per year. The total number of occupied territories on the whole of New Island in December 2009 was 333 (Fig. 1). During the survey, nests with 1-2 eggs (the normal clutch for skuas) were recorded at $72 \%$ of those territories.

The mean nesting success between 2003/04 and 2009/10 was $0.34 \pm 0.28$ chicks per laying pair $(N=7$ years; Table 1). This is a low value for Brown skuas Stercorarius antarctica, a species (which includes the Falkland skua subspecies) that, throughout its range, usually enjoys a high breeding success, often approaching or exceeding 1 chick per pair (e.g., Furness 1987, 1996; Mougeot et al. 1998; Phillips et al. 2004). Large skuas, and S. antarctica in particular, rarely start nesting before they are 6 years old (Furness 1987, 1996), which means that the recent population decline is unlikely to directly result from the low nesting success recorded in the recent years. It is plausible, however, that nesting success was also low during several years previous to 2003 .
Usually, immature skuas gather at specific sites (called clubs) on the nesting islands, in the years before they start breeding (Klomp and Furness 1992). In large colonies, such clubs are often attended by hundreds of birds (Klomp and Furness 1992; Phillips et al. 2004). It is, therefore, most telling that we have never been able to locate any club site at New Island. Most sites where a few skuas gathered (all near bathing sites) had such small numbers of individuals that we were uncertain as to whether they were true clubs or simply places where off-duty breeders congregated after bathing. This paucity of pre-breeders may be the result of a very poor past breeding success. Although not strictly comparable, figures presented for nesting skuas on New Island in 1988 and 1990 (Lamey 1995) suggest that breeding success was within normal values for the species at that time. Therefore, low breeding success may only have started later in the 1990s.

Large skuas usually have a high annual adult survival rate, not below 0.89 (reviewed in Ratcliffe et al. 2002). Hence, a population decline of $12.1 \%$ per year is rather close to what we would have expected in a scenario of zero recruitment. It is possible that, besides the low breeding success, the decline in numbers also resulted from an increased adult mortality, or perhaps from high levels of breeding deferral (Catry et al. 1998). Of 56 New Island breeding birds marked with numbered darvic rings in 2008-2009, 91\% returned the following nesting season, which suggest that adult survival may not be unduly low, but more data are needed to confirm this. Emigration is unlikely, as adult skuas are highly faithful to nesting colonies (Furness 1996). The lower number of territories recorded in December 2009 was not the result of an unusually high level of breeding deferral in that particular year, given that of the 51 adult birds recorded alive, only 11 (22\%) apparently did not attempt to nest. 
The consistently low breeding success and rapid population decline of skuas on New Island has not been paralleled by other seabird populations at the same site (own unpublished data). The main skua prey species on New Island (the thin-billed prion), for example, enjoyed a high breeding success between 1998 and 2006 (Catry et al. 2007), but there are no available data on its adult survival rates or population trends. A decline of unidentified food sources at sea seems an unlikely explanation for the patterns reported here. Skuas at New Island feed mostly on other birds and their eggs, and do not seem to fish much for themselves, which is confirmed by direct observations, pellet analyses and by GPS-tracking of breeders (own unpublished data). New Island hosts a population of feral cats, which could potentially prey on skuas, but cats have coexisted with skuas and other seabirds for over a century without noticeable impact at the population level and there are no confirmed instances of cat predation upon skuas (Matias and Catry 2008).

Interestingly, during the past two decades, another prion predator, the striated caracara Phalcoboenus australis has known a rapid population growth (15\% per annum) and, at least in the recent years, a high breeding success, with ca 2.5 fledglings per successful nest (Catry et al. 2008). The New Island caracara population was estimated at ca 306 individuals at the beginning of the 2006-2007 nesting season (Catry et al. 2008). The caracaras feed mostly on other birds, are known to be able to take skua eggs and chicks, and often monopolize carrion or steal prey from skuas, which do not seem to be able to present resistance to such kleptoparasitism (own obs.). Could the skua decline largely result from the population increase of its main competitor and predator? We believe this hypothesis to be plausible, but more research is needed and this and other factors must be examined in more detail. Meanwhile, the magnitude of the reported decline at the most important colony of this restricted-range skua subspecies should be the cause of some concern.

Acknowledgments We are grateful to Orea Anderson, Maria Dias, Riek van Noordwijk, Charles Swift, Nina Dehnhard and Laurent Demongin for help with fieldwork. The New Island Conservation Trust, an NGO and charity, supported field studies on their New Island reserve, through the supply of research facilities, accommodation and subsistence. This study was financed by Fundação para a Ciência e Tecnologia (FCT-Portugal) through Projecto Albatroz 2 (PTDC/MAR/099366/ 2008) and as part of the Programa Plurianual (UI\&D 331/94). RM received a grant from FCT (SFRH/BD/47378/2008). Further support was received from the Falkland Islands Government and from Caixa Geral de Depósitos (Portugal). Ian Strange, Maria Strange, Georgina Strange, Anton Wolfaardt, Leigh Wolfaardt and Helen Otley provided important logistical support.

\section{References}

Catry P, Phillips RA, Hamer KC, Ratcliffe N, Furness RW (1998) The incidence of non-breeding by adult great skuas and parasitic jaegers from Foula, Shetland. Condor 100:448-455

Catry P, Campos A, Segurado P, Silva M, Strange I (2003) Population census and nesting habitat selection of thin-billed prions Pachyptila belcheri on New Island, Falkland Islands. Polar Biol 26:202207

Catry P, Silva MC, MacKay S, Campos A, Masello J, Quillfeldt P, Strange IJ (2007) Can thin-billed prions Pachyptila belcheri breed successfully on an island with introduced rats, mice and cats? The case of New Island, Falkland Islands. Polar Biol 30:391-394

Catry P, Lecoq M, Strange IJ (2008) Population growth and density, diet and breeding success of striated caracaras Phalcoboenus australis on New Island, Falkland Islands. Polar Biol 31:1167-1174

Furness RW (1987) The skuas. T and A D Poyser, Calton

Furness RW (1996) Family stercorariidae. In: del Hoyo J, Elliott A, Sargatal J (eds) Handbook of the birds of the world, vol 3. Hoatzin to auks. Lynx Editions, Barcelona

Klomp NI, Furness RW (1992) Non-breeders as a buffer against environmental stress: declines in numbers of great skuas on Foula, Shetland, and predictions of future recruitment. J Appl Ecol 29:341-348

Lamey CS (1995) Chick loss in the Falkland skua Catharacta skua antarctica. Ibis 137:231-236

Matias R, Catry P (2008) The diet of feral cats on New Island, Falkland Islands and possible impact on breeding seabirds. Polar Biol 31:609-616

Mougeot F, Genevois F, Bretagnolle V (1998) Predation on burrowing petrels by the brown skua (Catharacta skua lonnbergi) at Mayes Island, Kerguelen. J Zool Lond 244:429-438

Phillips RA, Phalan B, Forster IP (2004) Diet and long-term changes in population size and productivity of brown skuas Catharacta antarctica lonnbergi at Bird Island, South Georgia. Polar Biol 27:555-561

Phillips RA, Catry P, Silk J, Bearhop S, McGill F, Afanasyev V, Strange IJ (2007) Movements, winter distribution and activity patterns of Falkland and brown skuas: insights from loggers and isotopes. Mar Ecol Prog Ser 345:281-291

Ratcliffe N, Catry P, Hamer KC, Klomp NI, Furness RW (2002) The effect of age and year on the survival of breeding adult great skuas Catharacta skua in Shetland. Ibis 144:384-392

Woods R, Woods A (1997) Atlas of breeding birds of the Falkland Islands. Anthony Nelson, Shropshire

Yorio P (2005) Estado poblacional y de conservación de gaviotines y escúas que se reproducen en el litoral marítimo Argentino. Hornero 20:75-93 